\title{
Effect of residues agricultural wastes on the productivity and quality of pleurotus colombinus I. by using polyethylene bags wall technique
}

\begin{abstract}
The investigation studied effect of residues of agriculture wastes by using polyethylene bag wall technique on Pleurotus colomninus L. srain 99 yield and their quality during both successive seasons of 2013/2014 and 2014/2015. The results indicated that different substrate formulas such as clover straw, wheat straw, sawdust, corn cob, soybean straw and rice straw gave significant differences characteristics of fruiting bodies, yield, biological efficiency, nutritional composition and mineral contents. The highest number counted fruit/bag was obtained from rice (14 and14.33 fruit/ bag) and wheat straw (14 and 13.33fruit/bag) in both seasons respectively. However, the elevated yield weight $(288.10$ and $317.33 \mathrm{~g} / \mathrm{bag}$ and biological efficiency $(82.26$ and $90.63 \%$ ) was found from soybean straw in both seasons respectively. The six substrates exhibited the suitable cultivation media and their effectiveness on physical characteristics such as stalk length, stalk diameter and cap diameter. Highest content of nitrogen $(2.50$ and $2.57 \mathrm{~g} / 100 \mathrm{~g})$ phosphorus $(2.50$ and $2.57 \mathrm{~g} / 100 \mathrm{~g})$ potassium $(2.54$ and $2.63 \mathrm{~g} / 100 \mathrm{~g})$ was achieved from clover straw in both seasons respectively. While the elevated contents of protein $(7.41$ and $7.24 \mathrm{~g} / 100 \mathrm{~g})$, carbohydrates $(31.40$ and $33.34 \mathrm{~g} / 100 \mathrm{~g})$ and energy (158.17 and165.91) obtained from soybean straw in both season respectively. Wheat straw substrate gave an increment fat $(0.42$ and $0.42 \mathrm{~g} / 100 \mathrm{~g})$ and fiber content $(5.42$ and $5.60 \mathrm{~g} / 100 \mathrm{~g}$ in both season respectively, on the other side corn cob substrate gave the highest ash content $(9.11$ and $9.30 \mathrm{~g} / 100 \mathrm{~g}$ in both seasons respectively. The raw and spent substrates were analyzed for their nutritional value composition.
\end{abstract}

Keywords: polyethylene bag wall, tss, protein, fat, carbohydrates, JUNCAO, biological efficiency, NPK
Volume 5 Issue 3 - 2016

\author{
Salama ANA,' Abdou AAK,' Helaly AA,' \\ Salem EA ${ }^{2}$ \\ 'Horticulture Department, Faculty of Agriculture, Al-Azhar \\ University, Cairo, Egypt \\ ${ }^{2}$ Central laboratory for agricultural climate, Giza, Egypt
}

\begin{abstract}
Correspondence: Helaly AA, Horticulture Department, Faculty of Agriculture,Al-Azhar University, Cairo, Egypt, Email alaahelaly@hotmail.com
\end{abstract}

Received: August 29, 2016 | Published: December 02, 2016

\section{Introduction}

Historically, the mushrooms have been used in denoting period before written records and prehistoric human as food. The Egyptians considered mushrooms as a delicacy and the Greeks believed that mushrooms provided strength for warriors in battle. The Romans regarded mushrooms as a gift from God and served them only on festive occasions, while the Chinese treasured them as a healthy food. ${ }^{1,2}$ Mushroom growing has a long tradition in Eastern Asia countries, especially in China, where it started around 600 A.D. with Auricularia auricular or also known as Wood Ear. In Europe, cultivation of Agaricus bisporus, the button mushroom, was first achieved in France during the seventeenth century. ${ }^{3}$ There are at least 12, 000 species of fungi that can be considered as mushrooms, with at least 2000 species are edible. ${ }^{4}$ More than 200 species have been collected from the wild and used for various traditional medical purposes, mostly in Far East. ${ }^{5}$ About 35 species have been cultivated commercially and 20 are cultivated on an industrial scale. Cultivation oyster mushroom in polyethylene bags patented technology invented by JUNCAO research institute at Fujian Agricultural and Forestry University (FAFU) in China. ${ }^{6-8}$

The number of fruits respected the harvested mature fruit bodies were counted per bag from first, second, third and fourth flush's. The number of fruiting bodies increased as the cow dung manure amendment percentage was increased ${ }^{9}$ also cultivated oyster mushroom on different substrates and reported that average number of fruiting bodies harvested ranged from 7.22 to 22.11 per bag. Bhatti et al., ${ }^{10}$ observed 2.73 to 7.3 fruiting bodies per bunch (cluster) while, Kanhar et al., ${ }^{11}$ recorded 11-28.66 fruit per bag. Total number of flushes (flush number) produced per each bag was noted. The distribution of the yield per flush was tabulated to observe changes in yield over the course of multiple flushes. Duration of time from inoculation to final harvest was calculated. There are about 200 kinds of waste in which edible mushrooms can be produced. ${ }^{12}$ The maximum mushroom yield (184.64g) per bag and biological efficiency $(62.87 \%)$ was obtained with the $30 \%$ cow dung manure on sisal leaves: sisal boles (50:50) substrate formulation. The lowest mushroom yield $(12.03 \mathrm{~g})$ per bag and biological efficiency $(8.95 \%)$ was obtained on non-supplemented sisal leave substrate. Generally, mushroom yield and biological efficiency results showed that were direct proportional with increasing supplement level regardless of the sisal waste substrate formulations employed. ${ }^{13}$ Similar trends of increasing yield with increasing supplement level to a certain optima have been reported on paddy straw substrate supplemented with different supplements. ${ }^{14}$ The yields results demonstrated that different sisal waste formulations supported the growth of Pleurotus HK-37 differently. ${ }^{13}$ The maximum value of T.S.S and ascorbic acid was found from soybean substrate, in the contrast, the lowest value of T.S.S and ascorbic acid content was obtained from rice straw substrate. On the other work, ascorbic acid was in the range of $12.52 \pm 0.3$ to $15.80 \pm 0.8 \mathrm{mg} / 100 \mathrm{~g}$. In the study maximum ascorbic acid in fruit bodies $(15.30 \pm 0.8 \mathrm{mg} / 100 \mathrm{~g} \mathrm{D.W}$.) was recorded on wheat straw, whereas the least concentration of ascorbic 
acid $12.52 \pm 0.3 \mathrm{mg} / 100 \mathrm{~g}$ (D.W.) was recorded when grown on paddy straw alone. ${ }^{8,15}$ Mineral content is also important for the nutritional value of mushrooms. The species provides a reasonable amount of minerals in comparison with vegetables. The evaluated strains differed in mineral content when grow on different substrates. Strain PG1 contained the highest percentage of nitrogen when grow on corn cob substrate. ${ }^{16}$ On the other hand the total nitrogen content when grow Pleurotus spp. on various substrates, the obtained data show that sisal leaf decortication residues contained significantly higher amount being $1.68 \%$ followed by sisal leaf decortication residues : sisal boles (25:75) being $1.53 \%$ while sisal boles recorded significantly lowest value being $1.14 \% .{ }^{13}$ On the other work the highest nitrogen content was found in the rice straw with grow oyster mushroom. ${ }^{17}$ The highest result of the nitrogen and phosphorus contents was found with soybean substrate, while, the minimum number of the nitrogen and phosphorus content was obtained with corn cob substrate. On the other hand, the highest protein and fat content was found with soybean substrate, while, the lowest result of protein content was obtained from corn cob substrate. In the other hand lowest value of fiber and fat content was found from wheat straw substrate. ${ }^{8,18}$

The objective of this study was to evaluate yield and nutritional composition of Pleurotus Colombinus L which grown on the different substrates to find out the relationship between the strain and their nutrients source seeking to have the suitable substrates for the production of the better mushroom quality by using wall of polyethylene bags technique.

\section{Materials and Methods}

The experiment was conducted in the vegetables laboratory, at Horticulture Department, Faculty of Agriculture in Cairo, AlAzhar University and central laboratory for agricultural climate at Dokki, Ministry of Agriculture during the two successive seasons of 2013/2014 and 2014/2015 under the environmental control of growth chamber. In this study, cultivar of mushrooms (Pleurotus colombinus $L$ starin19 was used to evaluate their characterization under different substrates by using JUNCAO technique for formula and produce oyster mushroom via polyethylene bags wall (Figure 1). The spores of the cultivar was obtained from Professor Lin Zhanxi of Fujian Agriculture and Forestry University FAFU) China. Six substrates formula were prepared for this experiment which were clover straw, wheat straw, sawdust, corncob, bean straw and rice straw. The straws of clover, wheat, sawdust, were obtained from agricultural field of local farmers in EL-Menofiya and corncob, bean and rice were obtained from Behiera governorate and chopped into small pieces (3-2 inches long). Each treatment was supplemented as the following JUNCAO formula: 1) Egyptian cloverstraw (Trifolium alexandrnum L.): $86 \%$ clover straw, $10 \%$ wheat bran, $2 \%$ gypsum powder (caso4) and $2 \%$ Caco3. 2) Wheat straw: $86 \%$ wheat straw, $10 \%$ wheat bran, $2 \%$ gypsum powder and 2\% Caco3. 3) Sawdust: $75 \%$ sawdust, $22 \%$ wheat bran, $1 \%$ sugar and $2 \%$ CaCo3. 4) Corn cob: $83 \%$ Corn cob, $15 \%$ wheat bran and $2 \% \mathrm{CaCo3}$. 5) Bean straw: $86 \%$ bean straw, $10 \%$ wheat bran, $2 \%$ gypsum and $2 \%$ CaCo3. 6) Rice straw: $98 \%$ rice straw and $2 \% \mathrm{CaCo}$. The mixture of each substrate and supplements was mixed thoroughly and adjusted it's $\mathrm{pH}$ in between 6.5-7. The substrates were soaked in tap water and about $60 \%-70 \%$ moisture was set to each substrate. $350 \mathrm{~g}$ wet substrate was filled in the polypropylene bag of $40 \mathrm{~cm} \times 18 \mathrm{~cm}$ in size and autoclaved at $121{ }^{\circ} \mathrm{C}$ at $1.5 \mathrm{lbs}$ pressure for two hours and allowed to cool overnight. After cooling, about $2.5 \%$ grain spawn were inoculated on the surface of substrate and incubated in a dark at controlled temperature of 25-27S. After colonization (full growth of mycelium), the plastic bags were cut from one side and placed in the growing room at temperature between $18-20^{\circ} \mathrm{C}$, relative humidity $85-9 \%$ and light intensity of 200-500lux. The treatments consisted of six substrates applied of the Pleurotus colombinus L. Cultivar from oyster mushroom was arranged in a randomized complete block) design factorial which have three replicates each consist of 10 of incubated substrate bags. The bags were then marked by permanent marker and were kept on the shelves in an incubation room and were allowed to complete the whitish mycelia growth under the suitable improvement for the three stages which are colonization, primordial initiation and date of first day of harvest in the cultivar of oyster mushrooms.

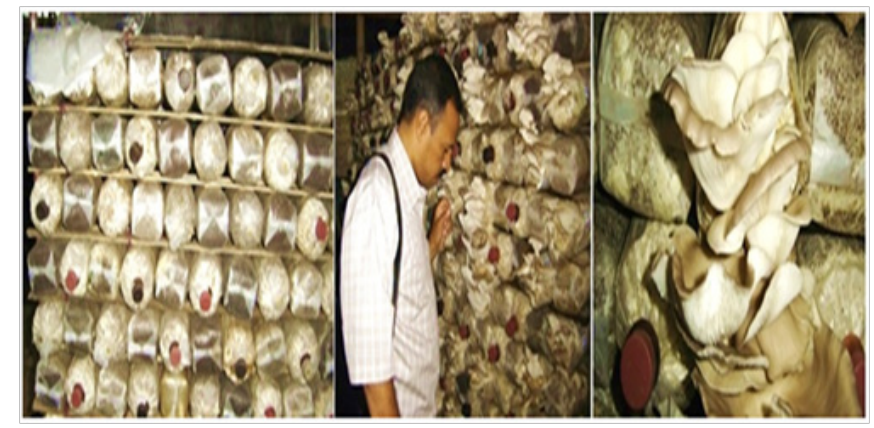

Figure I Oyster mushroom production via polyethylene bags wall technique.

\section{Yield}

i. Number of fruit /bag: The harvested mature fruit bodies were counted per bag.

ii. Total yield: The total weight ( $\mathrm{g}$ ) of the first flush, second flushes, third flush and fourth flush were calculated. Aqcfew

iii. Biological efficiency: The biological efficiency was defined as the percentage ratio of the fresh weight of harvested mushroom over dry weight of substrate. ${ }^{19}$

\section{Physical characteristics}

i. Stalk length $(\mathrm{cm})$ : The stalk length was measured by ruler from branching start point of junction.

ii. Stalk diameter $(\mathrm{cm})$ was measured by Vernier caliper.

iii. Diameter of cap of fruit body $(\mathrm{cm})$ : Diameter of cap was measured by Vernier caliper.

\section{Chemical characteristics}

i. TSS\% was determined by hand Refractometer according to $\mathrm{AOAC}^{20}$

ii. Ascorbic acid (mg/100g. f. W.) was determined by the method of titration with 2,6- dichlorophenol indophenol dye according to AOAC. ${ }^{20}$

iii. Nitrogen (g/100g. d. w.): The method for determining the nitrogen content was employed after Pella (1990). Phosphorus and Potassium (g/100g. d. w.): Phosphorus and Potassium content were determined using an inductively coupled plasma atomic emission Spectrometer (ICP-AES0) according to Pella. ${ }^{21}$ 
iv. Carbohydrates \%: The Total carbohydrate in mushroom sample was calculated by using the following equations: Carbohydrate $(\%)=[100-$ the contents of moisture - total ash - fiber - protein and fat].22

v. Protein \%: The crude protein content of the samples was estimated by the macro Kjeldhal method employed to find the total nitrogen content. The percentage content of the total nitrogen was multiplied by a factor of 6.25 to find the crude protein of the mushroom sample after AOAC. ${ }^{23}$

vi. Fat \%: Fat content in oyster mushroom sample was determined by extracting certain weight of powdered sample with petroleum ether using the soxhlet apparatus as described in the AOAC. ${ }^{23}$

vii. Fiber \%: The crude fiber was determined by acid and alkali digestion method on the mushroom sample according to the method reported by Raghuramuluet al., ${ }^{24}$

viii. Dry weight $(\mathrm{mg} / 100 \mathrm{~g}$.f .W. $)=$ Dry weight of certain weight/fresh weight the same weight $\times 100$ as reported.

ix. Ash \%: The ash content was determined by igniting the mushroom sample in silica crucibles in a muffle furnace at $620^{\circ} \mathrm{C}$ for 3 hours as described in $\mathrm{AOAC} .^{23}$

$\mathrm{x}$. Energy (Kcal/100gm): was determined by the equation after Sharma et al., $(2013)=[($ protein $\times 4)+($ Carbohydrate $\times 4)+($ fat $\times 9)]$

\section{Statistical analysis}

All experiments were statistically analyzed in a complete randomized design with three replicates. Obtained data were subjected to the analysis of variance procedure and means were compared by L.S.D. method at $5 \%$ level of significant according to Snedecor \& Cochran. ${ }^{25}$

\section{Results and discussion}

Six different types of substrates were investigated to determine the yield and their quality of Pleurotus colombinus $\mathrm{L}$. The number of fruits/ bag, weight fruit bodies/bag and biological efficiency percentage are presented in Table 1. The highest number of fruit bodies/bag was found from wheat straw which records number of 14.00 and 14.33 fruits/bag followed by rice straw with records of 14.00 and 13.33 fruits/bag in both seasons respectively. While, the lowest number of fruits body/ bag was obtained from sawdust with registered numbers 10 and 11.67 in both seasons respectively. This result may be due to the different substrate combination in both physical and nutritional composition as well as microclimates. ${ }^{26}$ Concerning to the maximum weight of fruit bodies/bag and biological efficiency \%/bag (Table 1) was obtained from sawdust substrate which registers heaviest weight 275.93 and $339.53 \mathrm{~g} / \mathrm{bag}$ and from soybean substrate 288.10 and $317.33 \mathrm{~g} / \mathrm{bag}$ in both seasons respectively. The biological efficiency $\%$ took the same trend which obtained from soybean substrate with recorded percentage 82.26 and $90.63 \%$ in both seasons respectively. This result may be due to the increases in yield of mushroom which grown in sawdust and soybean were similar to obtained result by Ponmurugan et al., ${ }^{27}$ which grew mushroom on body straw substrate gave the highest mushroom yield and that due to easier way of getting sugars from the cellulosic substances. These results may be due to the variation in these parameters could be explained by the fact that the texture and substrate formulations as well as nutrients in substrates possibly affected the composition of the final mushroom growth substrate and qualities such as water holding capacity and degree of aeration..$^{8,28,29}$ Yield and biological efficiency increases may be due to several factors. Firstly, the increased level of nutrient available at higher rates would provide more energy for mycelial growth and primordial formation. Secondly, supplement of soybean straw increased the water-holding capacity, and decreased the mortality of young fruiting bodies due to water shortage. ${ }^{30}$ The differences in terms of yield and biological efficiency of oyster mushrooms grown on different substrate types were due to the differences in physical and chemical composition of substrate formulas such as cellulose/lignin ratio and mineral contents, $\mathrm{pH}, \mathrm{EC}$ of substrate, especially $\mathrm{C} / \mathrm{N}$ ratio. ${ }^{8,31}$ There is a clear trend between the yield and nutrition consumption (Table 2-7) especially the nitrogen and carbohydrates which increased in spent substrates than raw substrates.

The tabulated data are presented in Table 2 show significant differences among the substrates in physical characteristics of oyster mushroom production. The longest stalk was observed in sawdust substrate which recording the number of 3.53 and $3.60 \mathrm{~cm}$ during the two seasons respectively, while the shortest of stalk was noticed with clover straw substrate with records of 2.14 and in the first season and soybean straw one with recorded number of $2.22 \mathrm{~cm}$ during the second season. Regarding to the maximum value of stake diameter was obtained from rice straw substrate which register number of 1.01 and $0.97 \mathrm{~cm}$ in the two season, while lowest number of stake diameter was obtained from wheat straw substrate which register number of $0.63 \mathrm{~cm}$ in the first season and sawdust which rerecording of 0.64 $\mathrm{cm}$ during the second season. The largest cap diameter was found from soybean straw substrate with records of 8.85 and $8.20 \mathrm{~cm}$ in the two seasons, in the contrast the lowest number of cap diameter was obtained from clover straw which records of $5.46 \mathrm{~cm}$ in the first season and rice straw substrate which rerecording $6.15 \mathrm{~cm}$ in the second season. On the whole, the temperature, relative humidity, fresh air, supplementation with, $\mathrm{C} / \mathrm{N}$ ratio and compact material were the major ecological factors affecting stalk length, stalk diameter and cap size in mushrooms. ${ }^{32}$ The $\mathrm{C} / \mathrm{N}$ ratio in mushroom substrate showed that low $\mathrm{N}$ content may be a limiting factor which in turn does not promote excessive growth of stalk length at the expense of good marketable yield ${ }^{33-35}$ ). Opposite resulted to those shown before are present the cap diameter which obtained from rice straw as it proved to the worst substrate may be due to its stiffness and difficult degradation by oyster mushroom. This may be attributed slowed down degraded during fructification of the cellulose, hemi cellulose and lignin which are the main constituents of rice straw. ${ }^{36,37}$

The nutritional composition of oyster mushroom (T.S.S, ascorbic acid and dry weight) are presented in Table 3 and differed significantly. The highest percentage of T.S.S was obtained from sawdust substrate which recording the 3.90 and $3.80 \%$ during both seasons respectively, while the lowest percentage of T.S.S content was found from rice straw substrate which recording 3.10 and $3.30 \%$ during the first and second seasons respectively. Concerning to the best values of the ascorbic acid content was found with wheat straw $(49.16$ and $51.23 \mathrm{~g} / 100 \mathrm{~g})$ and corn cob $(48.00$ and $43.73 \mathrm{~g} / 100 \mathrm{~g})$ in both seasons respectively, while the minimum value of ascorbic acid content was obedient from rice straw substrate with records of 26.60 and $24.73 \mathrm{~g} / 100 \mathrm{~g}$ in both seasons. Regarding to the maximum value of dry weight was obtained 
from corn cob which record of 11.70 and $11.97 \mathrm{~g} / 100 \mathrm{~g}$ in both seasons respectively, while soybean straw substrate exhibit dry weight value of 9.53 and $11.27 \mathrm{~g} / 100 \mathrm{~g}$ in the two seasons respectively. The lowest number of dry weight was obtained from wheat straw substrate with records number of 7.53 and $8.57 \mathrm{~g} / 100 \mathrm{~g} \mathrm{~cm}$ in the first and second season respectively. The highest amount of tss and dry matter was obtained from sawdust and corn cob respectively may be due to the high amount of NPK in the spent substrates (Table 7). TSS percentage may be increased due to loss in moisture content during storage and this is in agreement with Barwal et al., ${ }^{38}$ The rate constant is dependent on inverse absolute temperature by an Arrhenius type relationship. ${ }^{8,39}$ From the present study it can be said that wheat straw can be used to get good ascorbic acid to Oyster mushroom whatever not the same amount in leafy vegetable crops. Oyster mushroom can be consumed as one of the source of non-enzymatic antioxidant vitamins. Mushrooms are a group of fungi with good source of high quality proteins, rich in vitamins and minerals and high quality proteins, rich in vitamins and minerals and low calorie and cholesterol free. ${ }^{40}$ Both fresh and dry fruit bodies possess non-enzymatic antioxidant activities, but the maximum activities were found in case of fresh fruit bodies. So in order to get maximum of these activities, these fruit bodies should be stored in cold condition. Vitamins have tremendous role from medicinal point of view and due to these reasons mushroom can be consumed as a source of vitamins. ${ }^{41}$

Table I Effect of different substrates on yield and their components of Pleurotus colombinus L. during 2013/2014 and 2014/20I5 seasons

\begin{tabular}{lllllll}
\hline Characteristics & \multicolumn{2}{l}{ Number of fruits / bag } & \multicolumn{2}{l}{ Weight of fruits / bag(g) } & \multicolumn{2}{c}{ Biological efficiency/bag (\%) } \\
\hline Substrates & Ist Season & 2nd Season & Ist Season & 2nd Season & Ist Season & 2nd Season \\
\hline Clover straw & 12 & 12 & 221.6 & 281.07 & 63.44 & 80.27 \\
Wheat straw & 14 & 14.33 & 226.83 & 242.67 & 64.8 & 69.23 \\
Sawdust & 10 & 11.67 & 275.93 & 339.53 & 78.86 & 89.1 \\
Corn cob & 11 & 11.33 & 258.23 & 276.93 & 73.73 & 79.1 \\
Soybean straw & 10 & 11.67 & 288.1 & $317 . .33$ & 82.26 & 90.63 \\
Rice straw & 14 & 13.33 & 250 & 253.67 & 71.4 & 69.33 \\
L.S.D. at 5\% & 0.78 & 0.62 & 2.13 & 3.28 & 1.72 & 1.21 \\
\hline
\end{tabular}

Table 2 Effect of different substrates on physical characteristics of Pleurotus colombinus L. during 2013/2014 and 20I4/20I5 seasons

\begin{tabular}{lllllll}
\hline Characteristics & \multicolumn{2}{l}{ Stalk length cm } & \multicolumn{2}{c}{ Stalk diameter cm } & \multicolumn{2}{c}{ Cap diameter cm } \\
\hline Substrates & Ist Season & 2nd Season & Ist Season & 2nd Season & I st Season & 2nd Season \\
\hline Clover straw & 2.14 & 2.33 & 0.96 & 0.94 & 5.46 & 9.1 \\
Wheat straw & 2.53 & 2.74 & 0.63 & 0.96 & 8.81 & 7.85 \\
Sawdust & 3.55 & 3.6 & 0.91 & 0.64 & 7.8 & 8.17 \\
Corn cob & 2.67 & 2.65 & 0.88 & 1.02 & 7.64 & 7.01 \\
Soybean straw & 2.35 & 2.22 & 0.98 & 0.88 & 8.85 & 8.2 \\
Rice straw & 2.5 & 2.5 & 1.01 & 0.97 & 6.56 & 6.15 \\
L.S.D. at 5\% & 0.4 N & 0.22 & N.S & N.S & 0.46 & 0.3 \\
\hline
\end{tabular}


Table 3 Effect of different substrates on TSS, ascorbic acid and dry weight of Pleurotus colombinus L. during 20I3/ 20I4 and 20I4/20I 5 seasons

\begin{tabular}{lllllll}
\hline Characteristics & TSS \% & \multicolumn{2}{c}{ Ascorbic acid g/ I00g } & \multicolumn{2}{c}{ Dry weight g/ 00g } \\
\hline Substrates & Ist Season & 2nd Season & Ist Season & 2nd Season & Ist Season & 2nd Season \\
\hline Clover straw & 320 & 3.3 & 38.06 & 40.1 I & 8.67 & 9.35 \\
Wheat straw & 3 & 3.1 & 49.16 & 51.23 & 7.53 & 8.57 \\
Sawdust & 3.9 & 3.8 & 37.56 & 34.83 & 10 & 9.03 \\
Corn cob & 3.4 & 3.4 & 48 & 43.73 & 11.7 & 11.97 \\
Soybean straw & 3.3 & 3.5 & 33.83 & 36.9 & 9.53 & 11.27 \\
Rice straw & 3.83 & 3.76 & 26.6 & 24.73 & 7.97 & 10.5 \\
L.S.D. at 5\% & 0.15 & 0.22 & 1.16 & 1.22 & 1.03 & 1.18 \\
\hline
\end{tabular}

Table 4 Effect of different substrates on N. P. and K. of Pleurotus colombinus L. during the two seasons of 20I3/ 20I4 and 20I4/20I5

\begin{tabular}{|c|c|c|c|c|c|c|}
\hline \multirow{2}{*}{$\begin{array}{l}\text { Characteristics } \\
\text { Substrates }\end{array}$} & \multicolumn{2}{|c|}{ Nitrogen g/l 00g } & \multicolumn{2}{|c|}{ Phosphorus g/l00g } & \multicolumn{2}{|c|}{ Potassium g//00g } \\
\hline & Ist Season & 2nd Season & Ist Season & 2nd Season & Ist Season & 2nd Season \\
\hline Clover straw & 2.5 & 2.57 & 2.5 & 2.57 & 2.54 & 2.63 \\
\hline Wheat straw & 2.44 & 2.45 & 2.44 & 2.45 & 1.8 & 1.9 \\
\hline Sawdust & 0.73 & 0.75 & 0.73 & 0.75 & 3.83 & 3.71 \\
\hline Corn cob & 2.04 & 2.13 & 2.04 & 2.13 & 2.02 & 1.9 \\
\hline Soybean straw & I.II & I.II & I.II & I.II & 2016 & 1.94 \\
\hline Rice straw & 2.36 & 2.35 & 2.36 & 2.35 & 2.28 & 2.21 \\
\hline L.S.D. at $5 \%$ & 0.12 & 0.23 & 0.21 & 0.34 & 0.18 & 0.31 \\
\hline
\end{tabular}

Table 5 Effect of different substrates on protein, fat and fiber of Pleurotus colombinus L. during 20I3/ 20I4 and 20I4/20I5 seasons

\begin{tabular}{|c|c|c|c|c|c|c|}
\hline \multirow{2}{*}{$\begin{array}{l}\text { Characteristics } \\
\text { Substrates }\end{array}$} & \multicolumn{2}{|c|}{ Protein g/l00g } & \multicolumn{2}{|l|}{ Fat $g / 100 \mathrm{~g}$} & \multicolumn{2}{|c|}{ Fiber g/ $100 \mathrm{~g}$} \\
\hline & Ist Season & 2nd Season & Ist Season & 2nd Season & Ist Season & 2nd Season \\
\hline Clover straw & 4.06 & 4.183 & 0.28 & 0.28 & 4.43 & 4.6 \\
\hline Wheat straw & 2.97 & 2.99 & 0.42 & 0.42 & 5.42 & 5.6 \\
\hline Sawdust & 1.37 & 1.62 & 0.23 & 0.24 & 4.39 & 4.63 \\
\hline Corn cob & $\mathrm{I} .74$ & 1.91 & 0.18 & 0.19 & 3.43 & 4.12 \\
\hline Soybean straw & $7.4 I$ & 7.24 & 0.39 & 0.39 & 5.06 & 5.11 \\
\hline Rice straw & 4.8 & 4.68 & 0.33 & 0.34 & 5 & 5.01 \\
\hline L.S.D. at $5 \%$ & 0.37 & 0.82 & 0.12 & 0.17 & 0.45 & 0.39 \\
\hline
\end{tabular}

Table 6 Effect of different substrates on Carbohydrates ash and energy of Pleurotus colombinus L. during 20I3/ 20I4 and 20I4/20I5 seasons

\begin{tabular}{|c|c|c|c|c|c|c|}
\hline \multirow{2}{*}{$\begin{array}{l}\text { Characteristics } \\
\text { Substrates }\end{array}$} & \multicolumn{2}{|c|}{ Carbohydrates g/l00g } & \multicolumn{2}{|l|}{ Ash g/lo0g } & \multicolumn{2}{|l|}{ Energy } \\
\hline & Ist Season & 2nd Season & Ist Season & 2nd Season & Ist Season & 2nd Season \\
\hline Clover straw & 28.37 & 27.38 & 9.26 & 9.29 & 132.26 & 128.84 \\
\hline Wheat straw & 24.65 & 25.93 & 8.5 & 8.35 & 114.33 & 119.47 \\
\hline Sawdust & 25.02 & 24.62 & 9.03 & 9.11 & 107.64 & 107.06 \\
\hline Corn cob & 28.51 & 27.16 & 9.11 & 9.3 & 122.73 & 125.29 \\
\hline Soybean straw & 31.4 & 33.34 & 9 & 9.2 & 158.17 & 165.91 \\
\hline Rice straw & 25.83 & 27.33 & 7.72 & 7.79 & 125.45 & 143.67 \\
\hline L.S.D. at $5 \%$ & 1.23 & 1.17 & 0.55 & 0.27 & 2.12 & 1.98 \\
\hline
\end{tabular}


Table 7 The chemical analysis of raw and spent substrates before and after Pleurotus colombinus L. cultivation during the two season of $2013 / 2014$ and $2014 / 2015$

\begin{tabular}{|c|c|c|c|c|c|c|c|c|c|}
\hline \multirow{2}{*}{$\begin{array}{l}\text { Substrates } \\
\text { Characteristics }\end{array}$} & \multicolumn{3}{|c|}{ Clover straw } & \multicolumn{3}{|c|}{ Wheat straw } & \multicolumn{3}{|l|}{ Sawdust } \\
\hline & Raw & Spent1 & Spent 2 & Raw & Spent1 & Spent 2 & Raw & Spent1 & Spent 2 \\
\hline Nitrogen (g/100g d.w.) & 0.89 & 0.55 & 0.53 & 0.73 & 0.24 & 0.25 & 0.13 & 0.29 & 0.27 \\
\hline Phosphorus (g/100g d.w.) & 1.32 & 1.51 & 1.6 & 1.26 & 1.81 & 2.35 & 0.89 & 3.52 & 3.4 \\
\hline Potassium (g/100g d.w.) & 0.37 & 0.12 & 0.14 & 0.29 & 0.1 & 0.12 & 0.32 & 0.08 & 0.09 \\
\hline Protein (g/100g d.w.) & 5.56 & 3.43 & 3.37 & 4.56 & 1.5 & 2.1 & 0.81 & 1.81 & 1.7 \\
\hline Fat (g/100g d.w.) & 0.62 & 0.44 & 0.59 & 0.22 & 0.23 & 0.21 & 0.73 & 0.58 & 0.56 \\
\hline Fiber (g/100g d.w.) & 3.8 & 1.1 & 1.2 & 3.5 & 1.2 & 1.1 & 4.5 & 1.3 & 1.33 \\
\hline Carbohydrates (g/100g d.w.) & 67.82 & 78.52 & 78.78 & 74.65 & 82.87 & 83.17 & 68.49 & 79.36 & 79.31 \\
\hline Ash (g/100g d.w.) & 7.8 & 7.9 & 7.99 & 8.2 & 6.6 & 6.5 & 8.9 & 9.1 & 9.2 \\
\hline Substrates & \multicolumn{3}{|l|}{ Corn cob } & \multicolumn{3}{|c|}{ Soybean straw } & \multicolumn{3}{|l|}{ Rice straw } \\
\hline Characteristics & Raw & Spent1 & Spent 2 & Raw & Spent1 & Spent 2 & Raw & Spent1 & Spent 2 \\
\hline Nitrogen (g/100g d.w.) & 0.29 & 0.27 & 0.29 & 0.9 & 0.43 & 0.27 & 0.85 & 0.4 & 0.4 \\
\hline Phosphorus (g/100g d.w.) & 1.24 & 1.74 & 1.78 & 1.66 & 1.18 & 1.21 & 2.37 & 2.38 & 2.48 \\
\hline Potassium (g/100g d.w.) & 0.25 & 0.54 & 0.56 & 0.64 & 0.07 & 0.05 & 0.14 & 0.32 & 0.28 \\
\hline Protein (g/100g d.w.) & 1.81 & 1.68 & 1.84 & 5.62 & 2.68 & 1.73 & 5.31 & 2.5 & 2.56 \\
\hline Fat (g/100g d.w.) & 0.46 & 0.44 & 0.42 & 0.33 & 0.76 & 0.73 & 0.46 & 0.39 & 0.36 \\
\hline Fiber (g/100g d.w.) & 1.7 & 2.1 & 2.2 & 4.3 & 0.7 & 0.8 & 2.1 & 1.8 & 1.88 \\
\hline Carbohydrates (g/100g d.w.) & 75.39 & 78.99 & 78.99 & 71.01 & 80.27 & 79.88 & 67.49 & 75.95 & 75.9 \\
\hline Ash (g/100g d.w.) & 8.8 & 9 & 8.8 & 8.4 & 8.1 & 8.25 & 8.5 & 6.6 & 6.8 \\
\hline
\end{tabular}

Effect of different agricultural waste on nitrogen, Phosphorus, and potassium contents are presented in Table 4 with reachable high significant differences. The highest value of the nitrogen content was found from soybean substrate which recording the nitrogen content 1.19 and $1.16 \mathrm{~g} / 100 \mathrm{~g}$ and rice straw one with records of 0.77 and $0.75 \mathrm{~g} / 100 \mathrm{~g}$ during both seasons, while the lowest number of the nitrogen content was found from sawdust substrate which recording the nitrogen content 0.22 and $0.26 \mathrm{~g} / 100 \mathrm{~g}$ during the two seasons respectively. This result may be due to noteworthy the high content of nitrogen soybean straw substrate before cultivation as raw material in comparison to the other substrates. Hence the highest consumption of nitrogen content was revealed from the raw material soybean straw to the fruit body of the oyster mushroom which consumed the highest nitrogen and other nutritional composition. ${ }^{42,43}$ This result may be due to the soybean straw substrate consists of maximum nitrogen content before cultivation, subsequently was highest spent the cultivar with soybean straw nitrogen content in fruit body during the two seasons. While the minimum nitrogen content in soybean straw was found after oyster mushroom cultivation in both seasons (Table 7). The obtained result show the highest number of phosphorus content was found from clover straw with records of 2.50 and $2.57 \mathrm{~g} / 100 \mathrm{~g}$ and wheat straw substrate which recorded 2.44 and $2.55 \mathrm{~g} / 100 \mathrm{~g}$ in the two seasons respectively. In the contrast the lowest values of phosphorus was found with sawdust one with records of 0.73 and $0.75 \mathrm{~g} / 100 \mathrm{~g}$ in both season. Regarding to the maximum value of potassium content was obtained from sawdust which recording of 3.83 and $3.71 \mathrm{~g} / 100 \mathrm{~g}$ in the first and second season, while lowest number of potassium was obtained from wheat straw substrate which registers number of 1.80 and $1.90 \mathrm{~g} / 100 \mathrm{~g}$ in the first and second season respectively. The relative increase of the mineral content in spent substrates was also verified in other studies ${ }^{43-46}$ resulting from the cultivation of different Pleurotus strains in several agricultural residues. Oyster mushroom are high in protein, vitamins and essential elements including calcium, iron, magnesium, The highest results of protein content was found from soybean substrate which differ significantly and recording protein value 7.41 and $7.24 \mathrm{~g} / 100 \mathrm{~g}$ during both seasons, while, the lowest number of protein content was found from sawdust substrate which recording the number of 1.37 and $1.62 \mathrm{~g} / 100 \mathrm{~g}$ during the two seasons (Table 5). The highest protein content was found with raw soybean straw substrate before cultivation; subsequently the greatest protein content in the fruit bodies was obtained from soybean straw after cultivation as compared to the other substrates (Table 7). The protein content of mushrooms depends on several factors, such as the substrates chemical composition specially $\mathrm{C} / \mathrm{N}$ ratio, ${ }^{47,48}$ pileus size, cultivation time and strains. ${ }^{49}$ These factors were influenced by the chemical constituents the substrates, which reinforces the necessity of selecting suitable substrates and, in some cases, suitable nitrogen supplementation. ${ }^{50}$ These results are in accordance with protein values and reported by Sueli et al., ${ }^{51}$ Syed et al., ${ }^{52}$ The highest fat content was obtained from wheat straw substrate with records of $0.42 \mathrm{~g} / 100 \mathrm{~g}$ and soybean straw one which recorded 0.39 in the first and second season respectively, while the lowest fat content was found with corn cob substrate which records of 0.18 and $0.19 \mathrm{~g} / 100 \mathrm{~g}$ in both seasons (Table 5). This result may due to the fat content on dry weight basis lower 
than that of report by Wang et al., ${ }^{53}$ and much depends on the nature of substrate. These results are in accordance with the fat content values reported by Khydagi et al., ${ }^{54}$ Sueli et al., ${ }^{51}$ and Syed et al., ${ }^{52}$ Regarding to the maximum value of fiber content was obtained from wheat straw substrate which recording of5.42 and 5.62 and soybean straw one with records of 5.06 and $5.11 \mathrm{~g} / 100 \mathrm{~g}$ in the first and second season, while lowest number of fiber content was obtained from corn cob substrate which register 3.43 and $4.12 \mathrm{~g} / 100 \mathrm{~g}$ in the first and second season respectively. However the rich raw substrates in fiber contents may gave large qualities to be consumed by growing mushroom fruit bodies. These results were supported by the data reported by Khydagi et al., ${ }^{54}$ and Yehia $^{47}$ for crude fiber content.

The highest number of carbohydrates and energy contents (Table 6) was found from soybean substrate which recording the carbohydrates content 31.40 and $33.43 \mathrm{~g} / 100 \mathrm{~g}$ and energy of 158.17 and $165.91 \mathrm{kcal} / 100 \mathrm{~g}$ during the two seasons respectively, while, the lowest number of carbohydrates and energy content was found from sawdust substrate which recording the carbohydrates of 25.02 and $24.62 \mathrm{~g} / 100 \mathrm{~g}$ and energy content of 107.64 and $106.06 \mathrm{kcal} / 100 \mathrm{~g}$ during the first and second seasons respectively. This result may be attributed to the maximum carbohydrate content found in the soybean straw substrate before cultivation of oyster mushroom. As a notice and nature of the growing mushroom the soybean raw substrate consist of $75.51 \mathrm{~g} / 100 \mathrm{~g}$ carbohydrates. These results are in accordance with the high amount of total carbohydrate content was found in different Pleurotus species. ${ }^{55,56}$ This result may be due to the soybean straw substrate maximum highest carbohydrate content before cultivation, on the other side the highest carbohydrate content in fruit body for oyster mushroom with soybean straw substrate after cultivation (Table 7). Regarding to the maximum value of ash content (Table 6) was obtained from clover straw which recording of 9.26 and $9.29 \mathrm{~g} / 100 \mathrm{~g}$ and corn cob one with records of 9.11 and $9.30 \mathrm{~g} / 100 \mathrm{~g}$ in the first and second seasons respectively, while lowest number of ash was obtained from rice straw substrate which registers number of 7.72 and $7.79 \mathrm{~g} / 100 \mathrm{~g}$ in the first and second season respectively. Mushrooms are a potential source of total carbohydrates in the range of $42.62-66.78 \mathrm{~g} / 100 \mathrm{~g}$ and of protein in the range of $27.95-38.89 \mathrm{~g} / 100 \mathrm{~g}$ depending upon the species. Very low fat contents $1.34-6.45 \mathrm{~g} / 100 \mathrm{~g}$ makes mushroom a best diet for people suffering from heart diseases. ${ }^{57,58}$ Mona et al., ${ }^{59}$ investigated nutritional analysis and enzyme activities of Pleurotus ostreatus cultivated on citrus limonium and Carica papaya wastes and they concluded that fruit bodies containing $26.0-31.5 \%$ digestible protein, $20.9-33.0 \%$ total soluble carbohydrates and $2.0-5.9 \%$ fat (on dry basis). Several white rot fungi are edible mushrooms have been successfully cultivated at commercial level worldwide using lignocellulose wastes as substrates for their cultivation highest percentage of fat content. ${ }^{60}$ The most spent substrates from oyster mushroom has been found to be nutritionally rich with respect to its NPK contents, and being having high cation exchange capacity (Table 7). Spent mushroom substrate not only improves soil fertility but also helps in the turf establishment which, however, depends on the rate of spent mushroom substrate application in soil ${ }^{61}$ and Ahlawat and Sagar. ${ }^{62}$ The relative increase of the mineral content in spent substrates was also verified in other studies resulting from the cultivation of different Pleurotus strains in several agricultural residues and clarified that the mineral composition of the mushrooms fruit bodies varied with the kind of substrate. ${ }^{44-46,63}$

\section{Recommendations}

In seeking to follow the results in this experiment on Pleurotus colombinus by using polyethylene bags wall technique. Four points can be put in mind as recommendations for practical work. The first point recommended that the highest total weight of fruits (yield) and biological efficiency were obtained from corn cob and soybean straw substrates. The second advice is the largest cap diameter was found from soybean straw substrate. The third point, recommend the best quality and nutritional value as contents of nitrogen, protein, carbohydrates and energy were resulted from soybean straw substrate. The fourth point, suggest that oyster mushroom cultivation can play an important role in managing organic wastes whose disposal has become a problem. Malnutrition is a problem in developing countries and these wastes can be recycled into food and environment may be less endangered by pollution. The exploitation of spent mushroom substrate for the management of environment, agriculture and production of recyclable energy requires strict watch on its physical, chemical and microbiological properties.

\section{Acknowledgements}

Authors are grateful to Al-Azhar University, Faculty of Agriculture, Horticulture department, Government of Egypt for supporting this research project to carry out this work. An expression of gratitude to Prof. Dr. Shamel Ahmed Shanan at Horticulture Department, Faculty of Agriculture, Al- Azhar University, Cairo, Egypt. Special thanks and dedication go to Dr. Emad Abdelaziz Salem Senior Researcher in Central Laboratory for Agricultural Climate, Minestry of Agriculture for them help and assistance during carrying out this work and for supervision.

\section{Conflict of interest}

The author declares no conflict of interest.

\section{References}

1. Chang ST, Miles PG. Mushrooms: Cultivation, Nutritional Value, Medicinal Effect and Environment Impact. Boca Raton, USA: CRC Press; 2000. 480 p.

2. Jahan N, Moonmoon M, Shah MMI. Growers response to mushroom cultivation technologies disseminated by mushroom development project. J Agric Soc Sci. 2010;6:96-100.

3. Kues U, Liu Y. Fruiting body production in basidiomycetes. Application Microbiology and Biotechnology. 2000;54(2):141-152.

4. Chang S. Global impact of edible and medicinal mushrooms on human welfare in the 21 st century:non-green revolution. International Journal of Medicinal Mushrooms. 1999;(1):1-7.

5. Sanchez C. Modern aspects of mushroom culture technology. Appl Microbiol Biotechnol. 2004;64(6):756-762.

6. Zhanxi L. In Juncao technology. Fujian, China: Fujian Agricultural University; 1999.

7. Rajapakse JC, Rubasingha, Dissanyake P. The effect of six substrates on the growth and yield of American oyster mushrooms based on JUNCAO technology. The Journal of Agricultural Science. 2008;3(2):82-85.

8. Salama ANA, Abdou AAK, Helaly AA, et al. Cultivation of Pleurotus ostreatus L on different substrates based on JuNCAO technology in EGYPT. Nature and Science. 2016;14(4):59-66. 
9. Shah ZA, shray MA, Ishtiod MC. Comparative study on cultivation and yield performance of oyster mushroom (Pleurotus ostreatus) on different substrates (Wheat straw, Leaves and Sawdust). Pakistan Journal Nutrition. 2004;3(3):158-160.

10. Bhatti MI, Jiskani MM, Wagan KH, et al. Growth, development and yield of oyster Mushroom, Pleurotus ostreatus L. (jacq Ex Fr ) Kummer as affected by different spawn rates. Pak J Bot. 2007;39(7):2685-2692.

11. Kanhar Q, Jiskani D, Pathan MM, et al. Effect of urea on growth and yield of oyster mushroom, Pleurotus ostreatus (JACQ EX FR ) Kummer. Pakistan Journal Phytopathol. 2007;19(2):214-223.

12. Poppe J. Use of the agricultural waste materials in the cultivation of mushrooms. Science and cultivation of edible Fungi. 2000;1(2):3-23.

13. Prosper Raymond, Anthony M Mshandete, Amelia K Kivaisi. Cultivation of oyster mushroom (Pleurotus hk-37) on solid sisal waste fractions supplemented with cow dung manure. Journal of Biology and Life Science. 2013;4:1.

14. Patil KK, Kulkarni RV, Gupta DN. Enhancing yield and biological efficiency (be) in oyster mushroom by supplementation. Academic Journal Plant Sciences. 2011;4(2):41-44.

15. Patil SS, Ahmed SA, Telang SM, et al. The nutritional value of Pleurotus ostreatus (Jacq Fr ) Kumm cultivated on different lignocellulosic agrowastes. Inno Roma Food Biotech. 2010;7:66-76.

16. Guillamon NE, Lafuente AG, Lozano MD, et al. Edible mushrooms:role in the prevention of cardiovascular diseases. Fitoterapia. 2010;81(7):715723.

17. Adenipekun CO, Gbolagade JS. Nutritional requirements of Pleurotu sflorida (Mont) Singer A Nigerian mushroom. Pak J Nut. 2015;(5):597600 .

18. S Patil. Cultivation of Pleurotus sajor-cajuon different agro wastes. Science research reporter. 2012;2(3):225-228.

19. Pokhrel CP, Ohga S. Cattle bedding waste used as substrate in the cultivation of Agaricus blazei Murill. J Fac Agri Kyushu Univ. 2007;52:295-298.

20. association of official analytical chemists. official methods of analysis of aoac international. 17th ed. aoac international; 2000.

21. Pella E. Elemental organic analysis part 1 Historical developments. $A m$ Lab. 1990;22(3):116-125.

22. Sharma S, Kailash R, Yadav P, et al. Growth and yield of oyster mushroom (Pleurotus ostreatus) on different substrates. Journal New Biological Reports. 2013;2(1):3-8.

23. Association of official analytical chemists. Official Methods of Analysis $A O A C .15$ th ed. Washington DC, USA: AOAC; 1990.

24. Raghuramulu N, Nair MK, Kalayanasundaram S. A manual of laboratory techniques." 2nd ed. National institute of nutrition, Hyderabad, India: ICMR; 1983.

25. Snedecor GW, Cochran WG. Statistical Methods. 6th ed. Iowa, USA Iowa State Univ Press Ames; 1982.

26. Amin R, Alam SM, Sarker N, et al. Influence of different amount of rice straw per packet and rate of inocula on the growth and yield of oyster mushroom (Pleurotus ostreatus). Bangladesh J Mushroom. 2008;2:15-20.

27. Ponmurugan P, Sekhar YN, Sreesakthi TR. Effects of various substrates on the growth and quality of mushrooms. Pak J Biol Science. 2007;10(1):171-173.

28. Reyes RG, Lopez LLM, Kumakura K, et al. Coprinus comatus, a newly domesticated wild nutraceutical mushroom in the Philipines. Journal of Agriculture and Technology. 2009;5(2):299-316.

29. Kurtzman RH. Pasteurization of mushroom substrate and other solids. African Journal Environmental Science Technology. 2010;4(13):936-941.

30. Yang W, Guo FL, Wan. Yield and size of oyster mushroom grown on rice/wheat straw basal substrate supplemented with cotton seed hull. Saudi Biol Sci. 2013;20(4):333-338.

31. Hoa HT, Wang CL, Wang C. The effects of different substrates on the growth, yield, and nutritional composition of two oyster mushrooms (Pleurotus ostreatus andPleurotus cystidiosus). Microbiology. 2015;43(4):423-434

32. Amga. The Australian mushroom growers association (AMGA), Locked Bag 3, 2 Forbes St, Windsor, Australia: NSW; 2004. P 1-2.

33. Jandaik C, Thianga S. Studies on cultivation and food value of Macrolepiota procera mushroom. Science. 1981;1(2):725 -733.

34. Khare KB, Mutuku JM, Achwania OS, et al. Production of two oyster mushrooms, Pleurotus sajor-caju and P florida on supplemented and unsupplemented substrates. Bots J Agric Appl Sci. 2010;(6):4-11.

35. Onyango BO, Palapala VA, Arama PF, et al. Suitability of selected supplemented substrates for cultivation of Kenyan native wood ear mushrooms (Auricularia auricula). American Journal of Food Technology. 2013;6(5):395-403.

36. Laborde J, Lanzi G, Francescutti B, et al. Indoor composting: general principles and large scale development in italy. In: Chang ST et al. editors. Mushroom Biology and Mushroom Broducts. Hong Kong: The Chines University Press; 1993. p. 93-113.

37. Ragunathan R, Swaminathan K. Nutritional status of Pleurotus spp grown on various agro wastes. Food Chemistry. 2003;80(3):371-375.

38. Barwal VS, Sharma R, Singh TK. Development and evaluation of dietetic bitter gourd ready-to-serve drink. Journal of Food Science and Technology Mysore. 2005;42(2):202-205.

39. MHR Bhuiyan, MS Rana. Ketchup development from fresh mushroom Bangladesh research publications journal. 2012;7(2):182-188.

40. Selvi SP, Uma Devi, Suja S, et al. Comparison of non-enzymic antioxidant status of fresh and dried form of Pleurotus florida and Calocybe indica. Pakistan Journal of Nutrition. 2017;6(5):468-471.

41. Kumari D, Achal V. Effect of different substrates on the production and non-enzymatic antioxidant activity of Pleurotusostreatus (Oyster mushroom). Life Science Journal. 2008;5(3):73-76.

42. Ranged CO, Jandaik CL. Cultural studies on some Pleurotus spp. In Mushroom. 1997;3:9-13.

43. Ali MA, Mehmood MI, Nawaz R, et al. Influence of substrate pasteurization methods on the yield of oyster mushroom (Pleurotus species). Journal Agriculture Sciences. 2007;(44):300-303.

44. Zadrazil F. Cultivation of Pleurotus. In: Ghang ST, et al. editors. The Biology and Cultivation of Edible Mushrooms. New York, USA: Academic Press; 1978. p. 521-557.

45. Sturion GL. Use of banana leaf as a substrate for the cultivation of edible mushroom (Pleurotus spp). Thesis University of São Paulo, Piracicaba, Brazil (MSc in Food Science and Technology), Escola Superior de Agricultura Luiz de Queiroz, University of Sao Paulo - USP; 1994. 147 p.

46. Oliveira HCB. Three Substrates evaluation with different grain size for the Cultivation of Two Strains of Pleurotus ostreatus L (Jacq Fr) Kummer, Brazil: Federal University of Ceará Thesis; 2000. 89 p. 
47. Yehia SR. Nutritional value and biomass yield of the edible mushroom Pleurotus ostreatus cultivated on different wastes in Egypt. Innovative Romanian Food Biotechnology. 2012;11:9-14.

48. Mane VJ, Patil SS, Syed AA, et al. Bioconversion of low quality lignocellulosic agricultural wastes into edible protein Pleurotus sajor-caju (Fr)Singer. J Zhejiang Univ Sci B. 2007;8(10):745-751.

49. Bernas E, Jaworska G, Lisiewska Z. Edible mushrooms as a source of valuable nutritive constituents. Acta Scientiarum Polonorum Technologia Alimentaria. 2006;5(1):5-20.

50. Nunes MD. Nitrogen supplementation on the productivity and the chemical composition of oyster mushroom. Journal of Food Research. 2012;1(2):113-119.

51. Sueli OS, Sandra MG, dmar CE. Chemical composition of Pleurotu pulmonarious (fr.) quell Substrates and residue after cultivation. Brazilian Archives of biology and Technology. 2002;45(4):531-535.

52. Syed A, Kadam A, Mane JA, et al. Biological efficiency and nutritional contents of $P$ florida (Mont.) Singer cultivated on different agro wastes. Nature and Science. 2009;7(1):44-48.

53. Wang D, Sakoda A, Suzuki M. Biological efficiency and nutritional value of Pleurotus ostreatus cultivated on spent beet grain. Bioresour technol. 2001;78(3):293-300.

54. Khydagi KS, Sharada GS, Rao M. Proximate Composition of oyster mushrooms. Karnataka Journal Agricultural Sciences. 1998;11(2):548.

55. Akindahunsiand AA, Oyetayo FL. Nutrient and ant nutrient distribution of edible mushroom Pleurotus tuber-regium (Fries) Singer. LWT. 2006;(39):548-553.
56. Ogundele GF, Abdulazeez RO, Bamidele OP. Effect of pure and mixed substrate on oyster mushroom (Pleurotus ostreatus) cultivation. Journal of Experimental Biology and Agricultural Sciences. 2014;2(2S):215-219.

57. Beluham S, Ranogajec A. Chemical composition and non-volatile components of Croatian wild edible mushrooms. Food Chemistry. 2011;124(3):1076-1082.

58. Ashraf J, Ali MA, Ahmad W, et al. Effect of different substrate supplements on oyster mushroom (Pleurotus spp.) production. Food Science and Technology. 2013;1(3):44-51

59. Mona MR, Abdou HMAE, Nooman MUM. Nutritional analysis and enzyme activities of Pleurotus ostreatus cultivated on Citrus limonium and Carica papaya wastes. Aust J Basic \& Appl Sci. 2009;3(4):3352-3360.

60. Ingale A, Ramteke. Studies on cultivation and biological efficiencies of mushrooms grown on different agro residues. Innovative Rom Food Biotechnology. 2010;6:25-28.

61. Landschoot P, Nitt A Mc. Improving turf with compost. Biocycle. 1994;35(10):54-57.

62. Ahlawat OP, Sagar MP. Management of spent mushroom substrate. National Research Centre for Mushroom. Indian Council of Agricultural Research, Chambaghat, Solan, 173213; 2007.

63. Sales Campos C, da Eira AF, Minhoni MT, et al. Mineral composition of raw material substrate and fruiting bodies of Pleuroptus ostreatus $\mathrm{L}$ in culture. Interciencia. 2009;34(6):432-436. 